DOI: 10.14720/aas.2016.107.1.01

Agrovoc descriptors: wines; red wines/volatile compounds/phenolic compounds/phenols, organoleptic analysis/organoleptic properties

Agris category code: Q04

\title{
Volatile phenolics in Teran PTP red wine
}

\author{
Helena BAŠA ČESNIK ${ }^{1}$, Klemen LISJAK ${ }^{2 *}$
}

Received February 02, 2015; accepted February 16, 2016.

Delo je prispelo 02. februarja 2015, sprejeto 16. februarja 2016.

\begin{abstract}
The volatile phenolics, 4-ethylphenol, 4-vinylphenol, 4ethylguaiacol and 4-vinylguaiacol were quantified in Teran PTP wines that were produced in the Kras winegrowing district. The compounds were determined by using gas chromatography coupled with mass spectrometry after extraction with diethylether. Three years monitoring (2011, 2012, 2013 vintages) showed that all four undesirable compounds were identified in Teran PTP wines, however their content did not influence significantly the sensory characteristics of the wine. The average contents gained over the three-year period (2011-2013; $\mathrm{n}=82)$ were $153 \pm 193 \mu \mathrm{g} \mathrm{L}^{-1}$ for 4-ethylphenol, $1265 \pm 682 \mu \mathrm{g} \mathrm{L}{ }^{-1}$ for 4-vinylphenol, $69 \pm 94$ $\mu \mathrm{g} \mathrm{L}^{-1}$ for 4-ethylguaiacol and $128 \pm 106 \mu \mathrm{g} \mathrm{L^{-1 }}$ for 4vinylguaiacol. $7.3 \%$ of samples showed contents of 4ethylphenol above the odour threshold values. For 4vinylphenol, 4-ethylguaiacol and 4-vinylguaiacol that percentage was $98.8 \%, 25.6 \%$ and $91.5 \%$, respectively.
\end{abstract}

Key words: GC/MS, 4-ethylphenol, 4-vinylphenol, 4ethylguaiacol, 4-vinylguaiacol

\section{IZVLEČEK}

\section{HLAPNI FENOLI V RDEČEM VINU TERAN PTP}

V vinu Teran PTP, ki ga pridelujejo $\mathrm{v}$ vinorodnem okolišu Kras smo merili vsebnost hlapnih fenolov: 4-etilfenola, 4vinilfenola, 4-etilgvajakola in 4-vinilgvajakola. Spojine smo identificirali in jim merili vsebnost $\mathrm{s}$ plinsko kromatografijo sklopljeno $\mathrm{z}$ masno spektrometrijo, po ekstrakciji $\mathrm{z}$ dietiletrom. Triletno spremljanje (letniki 2011, 2012 in 2013) je pokazalo, da so $\mathrm{v}$ pridelanem vinu prisotne vse izpostavljene spojine prisotne $\mathrm{v}$ vinih Teran PTP, vendar njihove vsebnosti ne vplivajo na senzorične lastnosti vina. Povprečne vsebnosti, ki smo jih izmerili v vinu v triletnem obdobju so bile $153 \pm 193 \mu \mathrm{g} \mathrm{L}^{-1}$ za 4-etilfenol, $1265 \pm 682 \mu \mathrm{g} \mathrm{L}^{-}$ ${ }^{1}$ za 4-vinilfenol, $69 \pm 94 \mu \mathrm{g} \mathrm{L}{ }^{-1}$ za 4-etilgvajakol in $128 \pm 106 \mu \mathrm{g}$ $\mathrm{L}^{-1}$ za 4-vinilgvajakol. 7,3\% vzorcev je imelo vsebnosti 4etilfenola nad senzoričnim pragom zaznave. Za 4-vinilfenol, 4-etilgvajakol in 4-vinilgvajakol je bil ta delež 98,8 \%, 25,6 \% in $91,5 \%$.

Ključne besede: GC/MS, 4-etilfenol, 4-vinilfenol, 4etilgvajakol, 4-vinilgvajakol

\section{INTRODUCTION}

One of the most critical problems in the wine production is the appearance of undesirable aromatic compounds which can reduce the wine quality, especially in unpleasant tastes and smells, what can lead to high economic losses. One of these aromatic compounds is the so-called 'Brett' character, which is mainly related to the presence of ethylphenols (4-ethylphenol and 4ethylguaiacol) and vinylphenols (4-vinylphenol and 4-vinylguaiacol) (Pizarro et al., 2012). Low contents of these compounds contribute positively to the complexity of wine aroma, on the other hand, these same contents, above a certain threshold, can negatively affect the overall aroma of a wine (Silva et al., 2011). The 4-ethylphenol can produce the odour reminiscent of stable, horse sweat, or leather-like (Larcher et al., 2007), while 4-ethylguaiacol reminiscent of toasted bread, smoky, or clove odour (García-Carpintero et al., 2014) 4-vinylphenol, even if its content is under the sensory threshold, can give odours reminiscent of "band-aid" and gouache. However, these

\footnotetext{
Agricultural Institute of Slovenia, Hacquetova ulica 17, SI-1000 Ljubljana, Slovenia, PhD

2 Agricultural Institute of Slovenia, Hacquetova ulica 17, SI-1000 Ljubljana, Slovenia, PhD. e-mail: klemen.lisjak@kis.si, corresponding author
} 
compounds can be less detrimental if they are present in wine with 4- vinylguaiacol. 4vinylguaiacol contributes to the spicy note of wine. Various blends of ethylphenols in red wine give the wine unpleasant stable and animal-like odours (Larcher et al., 2007). Odour thresholds published in other papers on this topic are as follows: $440 \mu \mathrm{g}$ $\mathrm{L}^{-1}$ for 4-ethylphenol, $180 \mu \mathrm{g} \mathrm{L}^{-1}$ for 4-vinylphenol, $33 \mu \mathrm{g} \mathrm{L}^{-1}$ for 4-ethylguaiacol and $40 \mu \mathrm{g} \mathrm{L}^{-1}$ for $4-$ vinylguaiacol (López et al., 2002). Some authors have reported even higher odour thresholds for red wine: $620 \mu \mathrm{g} \mathrm{L}^{-1}$ for 4-ethylphenol and $140 \mu \mathrm{g} \mathrm{L}^{-1}$ for 4-ethylguaiacol (Alaňón et al., 2013). For 4vinylguaiacol, an odour threshold of $10 \mathrm{mg} \mathrm{L}^{-1}$ was also reported (García-Carpintero e tal., 2012) and $770 \mu \mathrm{g} \mathrm{L}^{-1}$ (Pour Nikfardjam et al., 2009) was reported for vinylphenols.

Volatile phenolics mainly arise from the metabolism of hydroxycinnamic acids by Brettanomyces/Dekkera sp. yeasts, which involves the sequential action of two enzymes. First, a cinnamate decarboxylase cleaves the phenolic acids directly into the corresponding vinylphenol and vinylguaiacol ( $p$-coumaric acid is cleaved to 4- vinylphenol and ferulic acid is cleaved to 4vinylguaiacol). Then, a vinylphenol reductase converts the 4-vinylphenol into 4-ethylphenol and 4-vinylguaiacol into 4-ethylguaiacol (Oelofse et al., 2009; Saez et al, 2011; Silva et al., 2011; Valentăo et al., 2007) It is known, that these yeasts can grow during bottle storage over long periods. They can produce 4-ethylphenol and 4ethylguaiacol contents that exceed critical olfactory thresholds during the first months of storage (Renouf et al., 2007). Careful hygienic precautions and adequately sulphuring the wines and wine containers can prevent the development of these undesirable yeasts (Valentăo et al., 2007).

The aim of the present work was to monitor the content of 4 volatile phenols in Teran PTP wine that was produced in the Kras winegrowing district of Slovenia between 2011- 2013. Teran PTP wine is produced exclusively from grapes of the grapevine variety 'Refošk' (Vitis vinifera L.) grown on absolute winegrowing sites at characteristic, intensive red colour soil, also known as 'jerina', which gives Teran PTP Recognized Traditional Denomination in EU.

\section{MATERIALS AND METHODS}

\subsection{Samples}

Samples of Teran PTP wine were collected from stainless steel tanks or wooden containers from wine producers in the Karst region of Slovenia. During three years of monitoring, 82 wines were sampled from different producers (39 from the 2011 vintage, 22 from the 2012 vintage and 21 from the 2013 vintage). Wines were sampled each year in May, 9 months after alcoholic fermentation and after completion of malolactic fermentation. One bottle of $0.75 \mathrm{~L}$ of each wine were sampled directly from the steel tanks or wooden containers. Wines were transported to Agricultural Institute of Ljubljana and kept at $15{ }^{\circ} \mathrm{C}$ until analyses. Analyses were performed during one month period after sampling.

\subsection{Extraction of volatile phenolics}

For extraction of volatile phenolics we used a method proposed by the Central Analytical Facility at Stellenbosch University in South Africa. A $20 \mathrm{ml}$ wine sample was transferred into a glass tube. Then the following was added: $400 \mu \mathrm{l}$ of internal standard 2,3-dimethyl phenol (99\% purity, dr. Ehrenstorfer) with $5 \mathrm{mg} \mathrm{L}^{-1}$ content in a model wine solution $(1 \mathrm{~g}$ of tartaric acid and $120 \mathrm{ml}$ of absolute ethanol p.a. filled up to $1 \mathrm{~L}$ with milliQ and $\mathrm{pH}$ adjusted to 3.5 with $\mathrm{NaOH}$ ). Afterwards 4 $\mathrm{ml}$ of diethylether (HPLC purity) was added. Then the tube was closed and sonicated for 30 minutes. The tube was shaken at 5 minutes intervals. After extraction, the organic phase was transferred to a glass vial using a Pasteur pipette. The vial contained sodium sulphate to dry the extract. The organic phase was then transferred to another clean vial and injected into a gas chromatograph coupled with a mass spectrometer (GC/MS).

\subsection{Identification and quantification of volatile phenolics}

To identify and quantify the volatile phenolics, a method proposed by the Central Analytical Facility at Stellenbosch University was used. The samples were analysed using a gas chromatograph (Agilent 
Technologies 7890A, Shanghai, China) equipped with a column DB-FFAP (Agilent Technologies, $60 \mathrm{~m}, 0.25 \mathrm{~mm}$ i.d., $0.5 \mu \mathrm{m}$ film thickness), with a constant flow of helium at $0.63 \mathrm{ml} \mathrm{min}{ }^{-1}$. The injector was held at $250{ }^{\circ} \mathrm{C}$. The $\mathrm{GC}$ oven was programmed as follows: $40{ }^{\circ} \mathrm{C}$ for $1 \mathrm{~min}$, from 40 to $150{ }^{\circ} \mathrm{C}$ at $20^{\circ} \mathrm{C} / \mathrm{min}$, from 150 to $240{ }^{\circ} \mathrm{C}$ at $5{ }^{\circ} \mathrm{C}$ $\min ^{-1}$, held at $240{ }^{\circ} \mathrm{C}$ for $8 \mathrm{~min}$. To determine the level of analytes, a mass spectrometer (Agilent Technologies 5975C, upgraded with a triple-axis detector, Palo Alto, CA, USA) was used. The temperature of the ion source was $230{ }^{\circ} \mathrm{C}$, the auxiliary temperature was $250{ }^{\circ} \mathrm{C}$, and the quadrupole temperature was $150{ }^{\circ} \mathrm{C}$. For qualitative determination, retention time and mass spectrum in selective ion monitoring mode (SIM) were used. The ions monitored were $\mathrm{m} / \mathrm{z} 137$ and 152 for 4-ethylguaiacol, m/z 107 and 122 for internal standard 2,3-dimethyl phenol, m/z 107 and 122 for 4-ethylphenol, $\mathrm{m} / \mathrm{z} 135$ and 150 for 4vinylguaiacol and $\mathrm{m} / \mathrm{z} \quad 91$ and 120 for 4vinylphenol. Ions 137, 107, 135 and 91 were the target ions used for quantification, whereas other ions were used as qualifier ions. Calibration standards were prepared by extracting model wine solutions with known concentrations of 4ethylphenol, 4-vinylphenol, 4-ethylguaiacol and 4vinylguaiacol.

\subsection{Validation parameters}

The limit of detection and the limit of quantification were estimated from chromatograms of standard solutions with known concentrations of 4-ethylphenol, 4-vinylphenol, 4-ethylguaiacol and 4-vinylguaiacol. The limit of detection (LD) was determined from $\mathrm{S} / \mathrm{N}=3$ and was $1.5 \mu \mathrm{g} \mathrm{L}^{-1}$. The limit of quantification (LOQ) was determined from $\mathrm{S} / \mathrm{N}=10$ and was $5.0 \mu \mathrm{g} \mathrm{L}^{-1}$.

Linearity was verified by using extracts of model wine solutions with known concentrations of 4ethylphenol, 4-vinylphenol, 4-ethylguaiacol and 4vinylguaiacol (five repetitions for one concentration level, eight concentration levels for the calibration curve). Linearity and range were determined by multiple linear regressions, using the $\mathrm{F}$ test. The linear model was fit and remained linear over the range from $5 \mu \mathrm{g} \mathrm{L}^{-1}$ to $2500 \mu \mathrm{g} \mathrm{L}^{-1}$; $\mathrm{R}^{2}$ is 0.9977 for 4-ethylphenol, 0.9991 for 4vinylphenol, 0.9978 for 4-ethylguaiacol and 0.9971 for 4-vinylguaiacol.

Trueness was verified by checking the recoveries. Ten spiked samples were prepared with red wine. The average of recoveries was calculated. The recoveries are presented in Table 1.

Table 1: Recoveries obtained during validation of analytical method for identification and measurement of volatile phenolics content

Preglednica 1: Izkoristki dobljeni med validacijo analizne metode za identifikacijo in merjenje vsebnosti hlapnih fenolov

\begin{tabular}{|l|r|r|r|}
\hline & Spiking level $\left(\mathrm{mg} \mathrm{L}^{-1}\right)$ & Recovery (\%) & \multicolumn{1}{c|}{ RSD (\%) } \\
\hline 4-ethylphenol & 0.05 & 77.6 & 12.6 \\
\hline 4-ethylphenol & 2 & 73.0 & 3.6 \\
\hline 4-vinylphenol & 2 & 103.4 & 12.3 \\
\hline 4-ethylguaiacol & 0.05 & 103.9 & 17.5 \\
\hline 4-ethylguaiacol & 2 & 91.9 & 3.0 \\
\hline 4-vinylguaiacol & 0.05 & 84.6 & 14.5 \\
\hline 4-vinylguaiacol & 2 & 92.2 & 4.7 \\
\hline
\end{tabular}

\subsection{Physico-chemical parameters}

The physico-chemical parameters of Teran PTP wine from the 2011, 2012, 2013 vintages were determined by standard EEC (1990) methods (European Union, 1990).

\subsection{Statistical analysis}

Data were collected and edited using Excel (Microsoft Office Professional Plus 2010) and analysis of variance (one-way ANOVA) was performed on content data for volatile phenolics using Statgraphics ${ }^{\circledR}$ Centurion XVI statistical software package (StatPoint Technologies). 


\section{RESULTS AND DISCUSSION}

The physico-chemical parameters of Teran PTP wine from the 2011, 2012, 2013 vintages are shown in Table 2. Teran PTP is a wine with a moderate alcohol level, elevated acidity and a lower $\mathrm{pH}$ (Table 2). The lower $\mathrm{pH}$ can be unfavourable for growth of Brettanomyces/Dekkera sp. Yeasts (Du Toit et al., 2005). In addition to this, the low alcohol content and low $\mathrm{SO}_{2}$ content, traditionally used in Teran PTP vinification and aging, can increase the risk of microbiology spoilage (Du Toit et al., 2005). It has been shown by numerous authors that a $0.8 \mathrm{mg} \mathrm{L}^{-1}$ molecular $\mathrm{SO}_{2}$ content is the optimum level to control almost all yeast and bacteria species ( $\mathrm{Du}$ Toit et al., 2005). However, due to the low free $\mathrm{SO}_{2}$ contents in Teran PTP wines, the molecular $\mathrm{SO}_{2}$ content (Table 2) is much lower than proposed for inhibiting any undesired Brettanomyces/Dekkera sp. yeasts in the wine.

Table 2: Average standard physico-chemical characteristics with standard deviations of Teran PTP wine for the 2011, 2012 and 2013 vintages

Preglednica 2: Povprečne standardne fizikalno-kemijske značilnosti s standardnimi odkloni vina Teran PTP letnikov 2011, 2012 in 2013

\begin{tabular}{|l|r|r|r|}
\hline \multicolumn{1}{|c|}{ Parameters } & \multicolumn{1}{c|}{$\begin{array}{c}2011 \text { vintage } \\
(\mathrm{n}=39)\end{array}$} & $\begin{array}{c}2012 \text { vintage } \\
(\mathrm{n}=22)\end{array}$ & $\begin{array}{c}2013 \text { vintage } \\
(\mathrm{n}=21)\end{array}$ \\
\hline alcohol (vol. \%) & $12.01 \pm 0.60$ & $11.95 \pm 0.58$ & $12.06 \pm 0.46$ \\
\hline molecular $\mathrm{SO}_{2}\left(\mathrm{mg} \mathrm{L}^{-1}\right)$ & $0.35 \pm 0.08$ & $0.41 \pm 0.03$ & $0.35 \pm 0.12$ \\
\hline free $\mathrm{SO}_{2}\left(\mathrm{mg} \mathrm{L}^{-1}\right)$ & $13 \pm 3$ & $12 \pm 1$ & $12 \pm 4$ \\
\hline total $\mathrm{SO}_{2}\left(\mathrm{mg} \mathrm{L}^{-1}\right)$ & $43 \pm 6$ & $40 \pm 9$ & $35 \pm 7$ \\
\hline $\mathrm{pH}$ & $3.37 \pm 0.13$ & $3.26 \pm 0.12$ & $3.33 \pm 0.14$ \\
\hline total acidity $\left(\mathrm{g} \mathrm{L}^{-1}\right.$ tartaric acid) & $7.5 \pm 0.7$ & $8.0 \pm 0.8$ & $7.5 \pm 0.8$ \\
\hline volatile acidity $\left(\mathrm{g} \mathrm{L}^{-1}\right.$ acetic acid $)$ & $0.62 \pm 0.17$ & $0.45 \pm 0.11$ & $0.73 \pm 0.13$ \\
\hline reducing sugars $\left(\mathrm{g} \mathrm{L}^{-1}\right)$ & $2.5 \pm 0.7$ & $1.2 \pm 0.3$ & $1.3 \pm 0.7$ \\
\hline
\end{tabular}

The results of the volatile phenolic content and their odour thresholds are presented in Table 3. By comparing results with ANOVA we obtained that there is a statistically significant difference only between contents of 4-ethylguaiacol and 4ethylphenol and contents of 4-ethylguaiacol and 4vinylphenol at the $95.0 \%$ confidence level. $7.3 \%$ of samples from the 2011-2013 vintages had content of 4-ethylphenol above odour threshold values described by Alaňón et al. (2013) and López et al. (2002). Portion of samples above the odour threshold values were $98.8 \%, 25.6 \%$ and $91.5 \%$ for 4-vinylphenol, 4-ethylguaiacol and 4vinylguaiacol respectively.

Table 3: Contents $\left(\mu \mathrm{g} \mathrm{L}^{-1}\right)$ of volatile phenolics in Teran PTP wine for the 2011, 2012 and 2013 vintages Preglednica 3: Vsebnosti ( $\mu \mathrm{g} \mathrm{L}^{-1}$ ) hlapnih fenolov v vinu Teran PTP letnikov 2011, 2012 in 2013

\begin{tabular}{|lr|r|r|r|r|}
\cline { 2 - 6 } \multicolumn{1}{c|}{} & \multicolumn{1}{c|}{2011} & \multicolumn{1}{c|}{2012} & \multicolumn{1}{c|}{2013} & \multicolumn{1}{c|}{$2011-2013$} & \multicolumn{1}{c|}{ odour threshold } \\
\hline 4-ethylphenol & $6-465$ & $23-593$ & $6-953$ & $6-953$ & 620 (a) \\
\hline 4-vinylphenol & $366-3438$ & $423-2454$ & $90-3376$ & $90-3438$ & $180(\mathrm{~b})$ \\
\hline 4-ethylguaiacol & $6-441$ & $6-479$ & $9-250$ & $6-479$ & $140(\mathrm{a})$ \\
\hline 4-vinylguaiacol & $28-750$ & $53-460$ & $19-345$ & $19-750$ & $40(\mathrm{~b})$ \\
\hline
\end{tabular}

(a) Alaňón et al., 2013; (b) López et al., 2002 
The average contents found during the 2011-2013 period were $153 \pm 193 \mu \mathrm{g} \mathrm{L}^{-1}$ for 4-ethylphenol, $1265 \pm 682 \mu \mathrm{g} \mathrm{L}^{-1}$ for 4-vinylphenol, $69 \pm 94 \mu \mathrm{g} \mathrm{L}^{-1}$ for 4-ethylguaiacol and $128 \pm 106 \mu \mathrm{g} \mathrm{\textrm {L } ^ { - 1 }}$ for 4- vinylguaiacol. The average contents of volatile phenolics for each vintage are presented in Figures $1-4$.

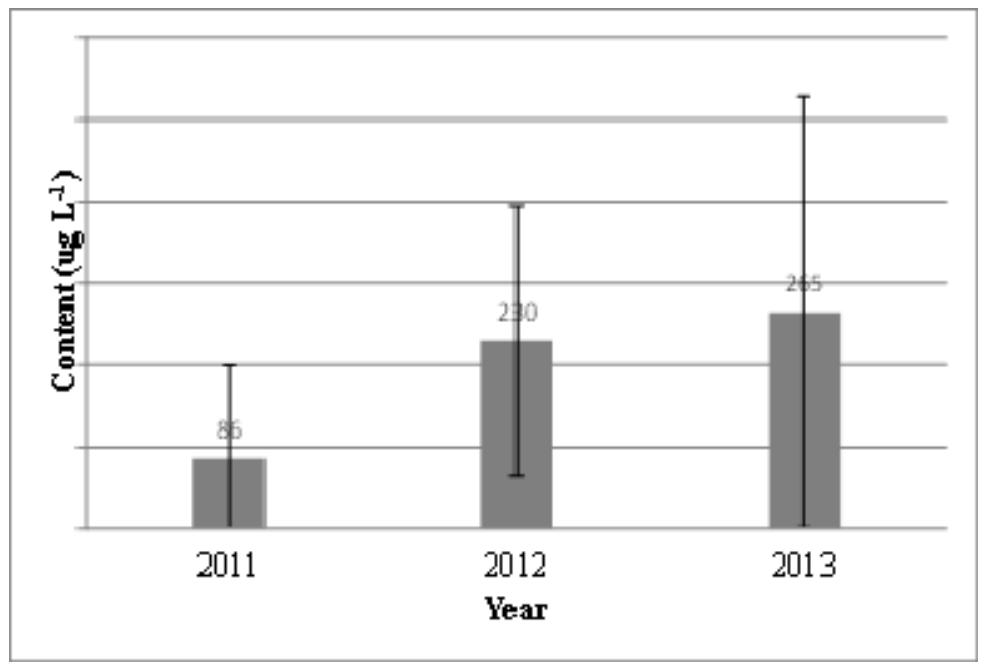

Figure 1: Average content and its standard deviation of 4-ethylphenol in Teran PTP wine from the 2011, 2012 and 2013 vintages

Slika 1: Povprečna vsebnost in njen standardni odklon za 4-etilfenol v vinu Teran PTP letnikov 2011, 2012 in 2013

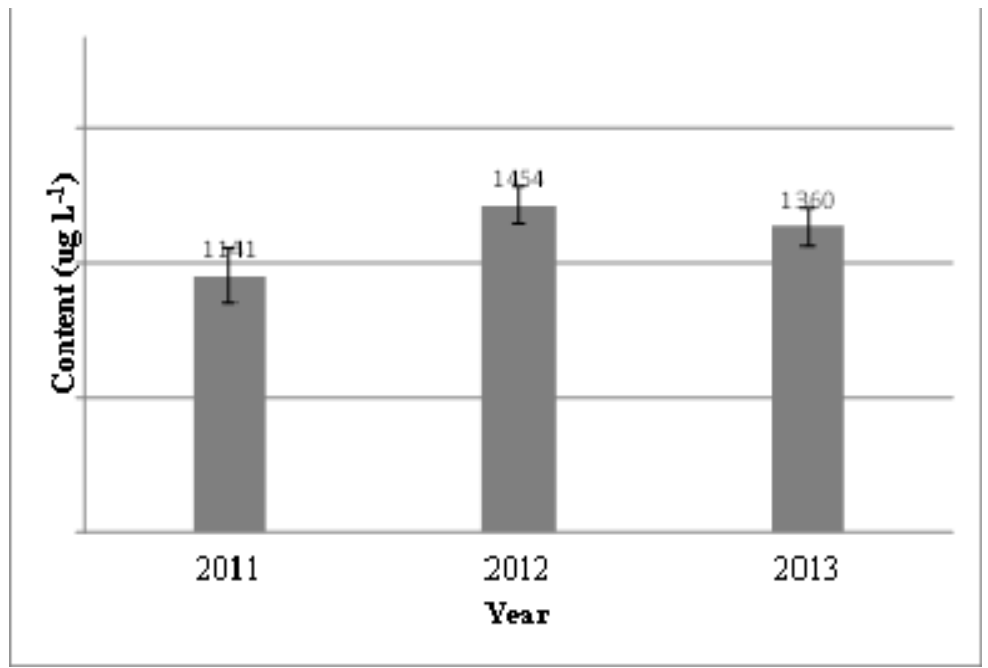

Figure 2: Average content and its standard deviation of 4-vinylphenol in Teran PTP wine from the 2011, 2012 and 2013 vintages

Slika 2: Povprečna vsebnost in njen standardni odklon za 4-vinilfenol v vinu Teran PTP letnikov 2011, 2012 in 2013 


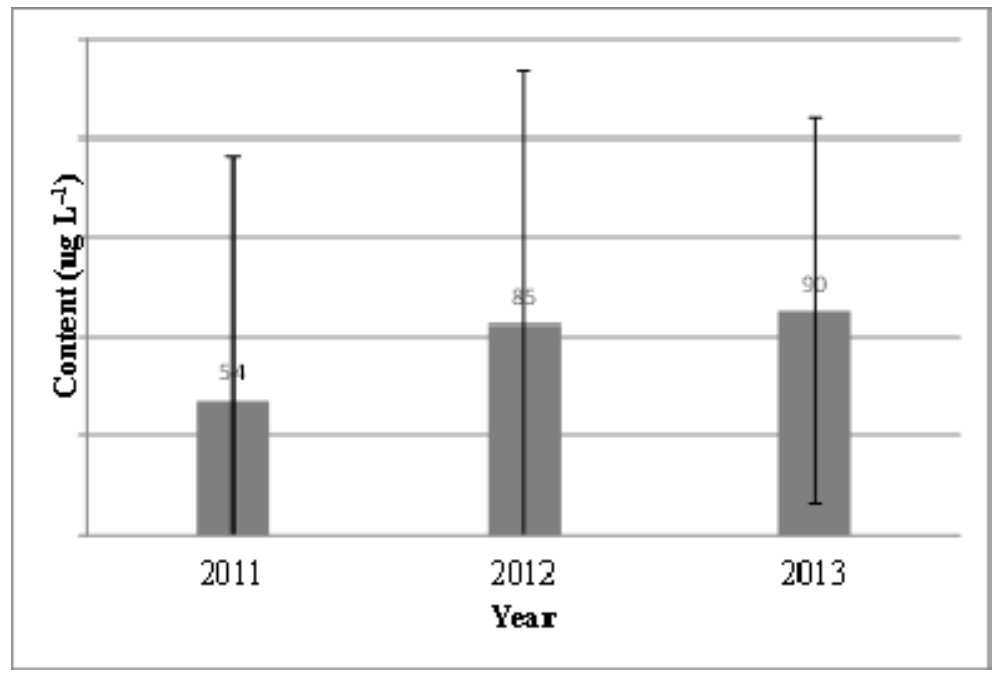

Figure 3: Average content and its standard deviation of 4-ethylguaiacol in Teran PTP wine from the 2011, 2012 and 2013 vintages

Slika 3: Povprečna vsebnost in njen standardni odklon za 4-etilgvajakol v vinu Teran PTP letnikov 2011, 2012 in 2013

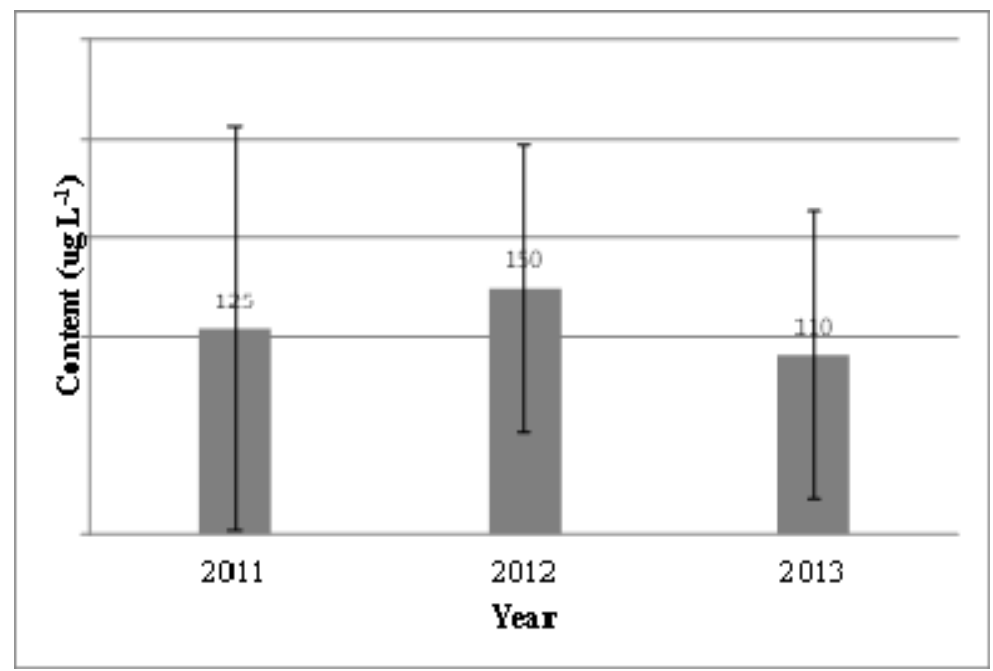

Figure 4: Average content and its standard deviation of 4-vinylguaiacol in Teran PTP wine from the 2011, 2012 and 2013 vintages

Slika 4: Povprečna vsebnost in njen standardni odklon za 4-vinilgvajakol v vinu Teran PTP letnikov 2011, 2012 in 2013

After comparing our results with the data from other published papers on volatile phenolics, we noticed that Spanish oak-aged red wine has similar contents of 4-ethylguaiacol (López et al., 2002).
Other wines also have similar contents of 4ethylphenol, 4-vinylphenol and 4-vinylguaiacol. A comparison of this data is presented in Table 4. 
Table 4: Comparison of volatile phenol content $\left(\mu \mathrm{g} \mathrm{L}^{-1}\right)$ in Teran PTP wine with similar data from other papers Preglednica 4: Primerjava vsebnosti hlapnih fenolov $\left(\mu g \mathrm{~L}^{-1}\right) \mathrm{v}$ vinu Teran PTP s podobnimi podatki iz drugih člankov

\begin{tabular}{|c|c|c|c|c|}
\hline & 4-ethylphenol & 4-vinylphenol & 4-ethylguaiacol & 4-vinylguaiacol \\
\hline Teran PTP red wine & $6-953$ & $90-3438$ & $6-479$ & $19-750$ \\
\hline red wine (a) & $101-133$ & n.a. & $88-105$ & n.a. \\
\hline red wine $(b)$ & $7-84$ & $730-4385$ & $42-65$ & $49-54$ \\
\hline red wine $(\mathrm{c})$ & $97-782$ & $1430-2174$ & $72-255$ & $282-880$ \\
\hline Tannat red wine $(d)$ & $170-1120$ & n.a. & 120 & n.a. \\
\hline Blaufränkisch red wine (e ) & $149-435$ & n.a. & $81-152$ & n.a. \\
\hline Spanish oak-aged red wine (f) & $8.6-1500$ & 8.1. -98 & $0.53-420$ & $5.4-236$ \\
\hline Moravia Dulce red wine (g) & n.d. & n.a. & n.d. & $287-473$ \\
\hline $\begin{array}{l}\text { archive wines } \\
\text { (vintage 1909-1981) } \\
\text { from Bordeaux region }(\mathrm{h})\end{array}$ & $1040-6410$ & n.a. & $122-975$ & n.a. \\
\hline
\end{tabular}

n.a. - not analysed

n.d. - not detected

(a) Pizarro et al., 2012, (b) Pizarro et al., 2007, (c) Domínguez et al., 2002, (d) Smit et al., 2003, (e) Díez et al., 2004, (f) López et al., 2002, (g) García-Carpintero et al., 2012, (h) Renouf et al., 2007

Due to lower $\mathrm{pH}$, typical for Teran PTP wine, the growth of Brettanomyces/Dekkera sp. yeasts can be reduced. This would reduce the possibility of forming volatile phenolics. In our report, more than $90 \%$ of the Teran PTP samples contained 4ethylphenol below the sensory threshold. However, it should be noted, that the wines were sampled in the spring time, when the temperatures in wine cellars might be still low. Low temperature can suppress the growth of undesirable microorganisms. The content of 4-ethylphenol in bottle-aged Teran PTP wines was reported to be 1016, 678 and $616 \mu \mathrm{g} \mathrm{L}^{-1}$ for the 2007, 2008 and 2009 vintages, respectively (Čuš et al., 2011).
To prevent the growth of Brettanomyces/Dekkera sp. yeasts and to prevent the formation of undesirable volatile phenolics it is necessary to either filter the wines during bottling or use $\mathrm{SO}_{2}$ (Du Toit et al., 2005; Renouf et al. (2007). Renouf et al. (2007) found Brettanomyces bruxellensis Kufferath and von Laer to be the most predominant yeast that grows during bottle storage over long periods. This yeast produces 4-ethylphenol and 4ethylguaiacol contents that exceed critical olfactory thresholds. A $1.0-\mu \mathrm{m}$ grade filter sheet was sufficient to eliminate all yeasts, and it significantly prevented the increase of volatile phenolics for several years after bottling (Renouf et al., 2007).

\section{CONCLUSIONS}

Ethylphenols (4-ethylphenol and 4-ethylguaiacol) and vinylphenols (4-vinylphenol and 4vinylguaiacol), which contribute to undesirable wine taste and smell were identified in Teran PTP wines. During three year monitoring (2011-2013 vintages) we measured contents of 4-ethylphenol and 4-ethylguaiacol in Teran PTP wines mainly below sensory threshold, while contents of 4vinylphenol and 4-vinylguaiacol were mainly above sensory threshold. Some phenolics were found, especially 4-vinylguaiacol, which can actually have a positive effect on wine aroma, reminiscent of a pepper or clove aroma. However, the volatile phenols that were found in Teran PTP wines were sampled and measured in late spring, when the temperatures in cellars might be still low, which could supress the growth of undesirable yeast. In order to reduce the risk of increased 
content of volatile phenolics, Teran PTP producers need to reduce the risk of growing Brettanomyces/Dekkera sp. yeasts. This can be accomplished by maintaining hygienic cellar conditions, by filtering the wine with $1.0-\mu \mathrm{m}$ grade filter sheets, and by proper sulfphiting of wine.

\section{ACKNOWLEGEMENTS}

The authors would like to thank the Teran PTP wine producers from the Karst region, Mateja Fortuna and the co-workers at the Central Laboratories of the Agricultural Institute of Slovenia. For help with introducing the method for determining volatile phenolics, we thank the Central Analytical Facility at Stellenbosch University in the Republic of South Africa. For financial support, we would like to express our thanks to the Agrotur/Karst agrotourism project, which was implemented as part of the CrossBorder Cooperation Programme Italy-Slovenia 2007-2013 - funded by the European Regional Development Fund and national funds. More information about the Agrotur project is available at http://www.agrotur.si/en/.

\section{REFERENCES}

Alaňón M. E., Schumacher R., Castro-Vázquez L., Díaz-Maroto I. J., Díaz-Maroto M. C., Pérez-Coello M. S. 2013. Enological potential of chestnut wood for aging Tempranillo wines part I: Volatile compounds and sensorial properties. Food Research International, 51: 325-334, DOI: 10.1016/j.foodres.2012.12.007

Čuš F., Gerič Stare B., Bach B., Barnavon L. 2011. Vsebnost biogenih aminov in hlapnih fenolov ter prisotnost kvasovke Brettanomyces bruxellensis $\mathrm{V}$ slovenskih vinih. Vinarski dan 2011, Ljubljana, 30. november 2011, pp. 5-24

Díez J., Domíniguez C., Guillén D. A., Veas R., Barroso C. G. 2004. Optimisation of stir bar sorptive extraction for the analysis of volatile phenols in wines. Journal of Chromatography A, 1025: 263267, DOI: 10.1016/j.chroma.2003.10.073

Domínguez C., Guillén D. A., Barroso C. G. 2002. Determination of volatile phenols in fino sherry wines. Analytica Chimica Acta, 458: 95-102. DOI: 10.1016/S0003-2670(01)01581-1

Du Toit W., Pretorius I., Lonvaud-Funel A. 2005. The effect of sulphur dioxide and oxygen on the viability and culturability of a strain of Acetobacter pasteurianus and a strain of Brettanomyces bruxellensis isolated from wine. Journal of Applied Microbiology, 98: 862-871, DOI: 10.1111/j.13652672.2004.02549.x

European Union 1990. Commission Regulation (EEC) No. 2676/90 determining Community methods for the analysis of wines

García-Carpintero E.G., Sánchez-Palomo E., Gómez Gallego M. A., González-Viňas M. A.. 2012. Free and bound volatile compounds as markers of aromatic typicalness of Moravia Dulce, Rojal and Tortosí red wines. Food Chemistry, 131: 90-98, DOI: $10.1016 /$ j.foodchem.2011.08.035

García-Carpintero E. G., Sánchez-Palomo E., Oliveria González Viňas M. A. 2014. Volatile composition of Bobal red wines subjected to alcoholic/malolactic fermentation with oak chips. Food Science and Technology, 55: 586-594, DOI: 10.1016/j.lwt.2013.10.024

Larcher R., Nicolini G., Puecher C., Bertoldi D., Moser S., Favaro G. 2007. Determination of volatile phenols in wine using high-performance liquid chromatography with a coulometric array detector. Analytica Chimica Acta, 582: 55-60, DOI: 10.1016/j.aca.2006.08.056

López R., Aznar M., Cacho J., Ferreira V. 2002. Determination of minor and trace volatile compounds in wine by solid-phase extraction and gas chromatography with mass spectrometric detection. Journal of Chromatography A, 966: 167177. DOI: 10.1016/S0021-9673(02)00696-9

Oelofse A., Lonvaud-Funel A., Du Toit M.. 2009. Molecular identification of Brettanomyces bruxellensis isolated from red wines and volatile phenol production. Food Microbiology, 26: 377385, DOI: 10.1016/j.fm.2008.10.011

Pizarro C., Pérez-del-Notario N., González-Sáz J. M. 2007. Multiple headspace solid-phase microextraction for eliminating matrix effect in the simultaneous determination of haloanisoles and volatile phenols in wines. Journal of 
Chromatography A, 1166: 1-8, DOI: 10.1016/j.chroma.2007.08.031

Pizarro C., Sáenz-González C., Pérez-del-Notario N., González-Sáiz J. M. 2012. Optimisation of a sensitive method based on ultrasound-assisted emulsification-microextraction for the simultaneous determination of haloanisoles and volatile phenols in wine. Journal of Chromatography A, 1244: 3745, DOI: $10.1016 /$ j.chroma.2012.04.070

Pour Nikfardjam M., May B., Tschiersch C. 2009. Analysis of 4-vinylphenol and 4-vinylguaiacol in wines from the Württemberg region (Germany). Mitteilungen Klosterneuburg, 59: 84-89

Renouf V., Perello M.-C., De Revel G., Lonvaud-Funel A. 2007. Survival of wine microorganisms in the bottle during storage. American Journal of Enology and Viticulture, 58: 379-386

Saez J. S., Lopes C. A., Kirs V. E. 2011. Production of volatile phenols by Pichia manshurica and Pichia membranifaciens isolated from spoiled wines and cellar environment in Patagonia. Food Microbiology, 28: 503-509, DOI: 10.1016/j.fm.2010.10.019

Silva I., Campos F. M., Hogg T., Couto J. A. 2011. Factors influencing the production of volatile phenols by wine lactic acid bacteria. Internatuional Journal of Food Microbiology, 145: 471-475, DOI: 10.1016/j.ijfoodmicro.2011.01.029

Smit A., Cordero Otero R., Lambrechts M. G., Pretorius I. S., Van Rensburg P. 2003. Enhancing volatile phenol concentrations in wine by expressing various phenolic acid decarboxylase genes in Saccharomyces cerevisiae. Journal of Agricultural and Food Chemistry, 51: 4909-4915, DOI: $10.1021 / j$ f026224d

Valentăo P., Seabra R. M., Lopes G., Silva L. R., Martins V., Trujillo M. E., Velázquez E., Andrade P. B. 2007. Influence of Dekkera bruxellensis on the contents of anthocyanins, organic acids and volatile phenols of Dăo red wine. Food Chemistry, 100: 64-70, DOI: 10.1016/j.foodchem.2005.09.010 